\title{
Effect of Some Integrated Pest Management Elements on the Population Density of Bemisia Tabaci (Gennadius) (Hemiptera: Aleyrodidae) on Tomato Plants (Solanum Lycopersicum L.)
}

\author{
Adnan A. E. Darwish ${ }^{1 *}$, Mohammed M. R. Attia ${ }^{1}$ and Alaa M. H. Khozimy ${ }^{1}$
}

\begin{abstract}
Management of the whitefly, Bemisia tabaci (Gennadius) is considered one of the challenges to worldwide scientists and famers for achieving agricultural and environmental sustainability. In this work, we studied the effect of plant spacing, different combination of chemical fertilizers, treatment with potassium silicate, diurnal activity and some of chemical insecticides on the population density of $B$. tabaci on tomato plants under field conditions. The results showed that minimum population of whitefly nymphs were recorded to be per tomato leaves from those plots where maximum plant spacing $(50 \mathrm{~cm})$ was maintained. The results of effect of different rates of chemical fertilizers revealed that the treatment with nitrogen fertilizer was the most important factor affecting the population density of $B$. tabaci followed by potassium fertilizers and finally phosphorus fertilizers. The results also confirm that there are positive correlations between population densities of $B$. tabaci and levels of nitrogen fertilizer on tomato plants. The results concerning the diurnal activity of adults of $B$. tabaci clearly shown that there are significantly greater numbers of adults of $B$. tabaci were collected at 10:00 am and 11:00 am in summer and nili plantations, respectively compared with the other different times of the day. The tested insecticides against $B$. tabaci nymphs can be arranged as follows sulfoxaflor, thiamethoxam, acetamiprid, pyriproxphene, buprofezin and finally dinotefuran.
\end{abstract}

Key words: Bemisia tabaci, plant spacing, potassium silicate, chemical fertilization, circadian rhythm, insecticides.

\section{INTRODUCTION}

Tomato (Lycopersicon esculentum Mill.) is one of the most important vegetables crop in the world, including Egypt. The cultivated area in Egypt (in 2015) estimated by about 469,000 fed (197 thousand ha) with an average yield of 16.28 tons per fed., and about 7.7 million tons as a total production (Siam and Abdelhakim, 2018). From sowing until harvest, tomato plants are subject to attack by several insect pests. Whitefly Bemisia tabaci (Gennadius) (Hemipetra: Aleyrodidae) is one of the most destructive insect pests which attack the tomato plants (Firdaus, et al., 2012; Mahmoud, 2017; Jahel, et al., 2017; Prado Maluta, et al. 2020). Agriculturally and economically, the whitefly, B. tabaci is one of the most important insect pests worldwide, it attacks a broad spectrum of hosts (extremely polyphagous insect pest) (Perring, 2001; Stansly and Naranjo, 2010; Shao-Jian, et al. 2011). By using its piercing sucking mouth parts, the whitefly punctures the leaf tissue and feed on the phloem; excretion of honeydew which followed by development of black sooty mold fungi, reduces plant vitality and consequently productivity causing great losses in the yield of its plant hosts (Palumbo et al., 2000). In addition to direct damage, the whitefly transmits several plant viruses to tomato plants (indirect damage) (Polston, et al. 2014; Rojas, et al. 2018; Prado Maluta, et al. 2020). Many factors can affect the population density of whitefly in its plant hosts such as the weather factors (Jha and Kumar, 2017; Aregbesola, et al., 2019), different fertilization rates (Idriss, et al., 2015), planting spaces, dates and varieties (Mohamed, 2012). Any comprehensive integrated pest management (IPM) program requires an understanding of the pest's ecological information and the ecological relationships between crops, pests, and the environment. Thus, keeping in view the above information, in the present study, an effort was made to study the effect of some integrated pest management elements on the population density of Bemisia tabaci (Gennadius) (Hemiptera: Aleyrodidae) on tomato plants (Solanum lycopersicum L.). These elements included effect of plant spacing, different combination of chemical fertilizers, foliar spray with potassium silicate, diurnal activity and some insecticides in an attempt to develop the integrated pest management programs of this insect pest.

\section{MATERIALS AND METHODS}

Field experiments were carried out throughout two successive seasons (2019 and 2020) on tomato plants variety "Super strain B" at Nobaria district, Beheira Governorate, Egypt. Five separated experiments were conducted as follows:

Effect of plant spacing (plant density) of tomato plants on the population density of $B$. tabaci nymphs:

The $1^{\text {st }}$ experiment was set up to study the effect of plant spacing (plant density) of tomato plants on the population density of $B$. tabaci. The experiment was laid out in a randomized complete block design (RCBD) with four replications (a single factor trial). Four treatments of

DOI: 10.21608/ASEJAIQJSAE.2021.149092

${ }^{1}$ Plant protection department, Faculty of Agriculture, Damanhour University, Egypt

*corresponding author, adnandarwish2012@yahoo.com

Received January 07, 2021 , Accepted February 16, 2021. 
different plant spacing namely $20 \mathrm{~cm}$ (about 50000 plants $\mathrm{ha}^{-1}$ ), $30 \mathrm{~cm}$ (about 30000 plants $\mathrm{ha}^{-1}$ ), 40cm (about 25000 plants $\mathrm{ha}^{-1}$ ) and $50 \mathrm{~cm}$ (about 20000 plants ha ${ }^{-1}$ ) on the one side of beds, $100 \mathrm{~cm}$ width (1 $\mathrm{m}$ between rows). The experiment comprised of 16 plots, each measuring $6 \mathrm{~m} \times 5 \mathrm{~m}$, and $1 \mathrm{~m}$ between replications. At weekly interval, samples of 10 leaflets were picked from each replicate. The samples collected, placed in paper bags and transferred to the laboratory for examination under a stereomicroscope to determine number of nymphs /leaflets. The seedlings were planted at the experimental site on mid-February in the summer plantation and in mid-July in the nili plantation. The sampling was started 15 days post seedlings planting and continues up to the end of the season. During the growing seasons, all the recommended agriculture practices were performed as usual. No pesticides were used throughout the experiment.

\section{Effect of different combination of chemical fertilizers on the population density of $B$. tabaci:}

The present experiment aimed to study the effect of different rates of chemical fertilizers on the population density of $B$. tabaci. The experiment was laid out in a randomized complete block design (RCBD) with four replications. Seven treatments of different chemical fertilizers rates were tested as follow:

1- $120 \mathrm{~N}: 50 \mathrm{P}: 100 \mathrm{~K}$ (control)

2- 180N: 50 P: $100 \mathrm{~K}$ (150\% of recommended nitrogen rate)

3- $60 \mathrm{~N}: 50 \mathrm{P}: 100 \mathrm{~K}$ (50 \% of recommended nitrogen rate)

4- $120 \mathrm{~N}$ : 75 P: $100 \mathrm{~K}$ (150\% of recommended phosphorus rate)

5- $120 \mathrm{~N}: 25 \mathrm{P}: 100 \mathrm{~K}(50 \%$ of recommended phosphorus rate)

6- $120 \mathrm{~N}$ : $50 \mathrm{P}: 50 \mathrm{~K}$ (50\% of recommended potassium rate)

7- $120 \mathrm{~N}$ : $50 \mathrm{P}: 150 \mathrm{~K}$ (150\% of recommended potassium rate)

Each treatment of $\mathrm{N}: \mathrm{P}: \mathrm{K}$ ratio was applied to the soil in four amounts in 15, 45, 65 and 85 days after transplanting. All the remaining agricultural practices were adopted as usual. The chemical fertilizers which used in this experiment were ammonium sulfate $(20.6 \%$ $\mathrm{N})$ and/or ammonium nitrate $(33.5 \% \mathrm{~N})$ as a source of nitrogen $(\mathrm{N})$, potassium sulphate $\left(24 \% \mathrm{~K}_{2} \mathrm{SO}_{4}\right)$ and super phosphate $\left(\begin{array}{lll}15 \% & \mathrm{P}_{2} \mathrm{O}_{5}\end{array}\right)$ as sources of potassium and phosphorus, respectively. Population density of whitefly nymphs was monitored weekly during a growing season (as mentioned above). Weekly10 leaflets were picked from each replicate, placed in paper bags and transferred to the laboratory for examination under a stereomicroscope to determine number of nymphs /leaflets.

The samples were taken as mentioned above. Weekly10 leaflets were picked from each replicate, placed in paper bags and transferred to the laboratory for examination under a stereomicroscope to determine number of nymphs /leaflets.

\section{Effect of the foliar application with potassium silicate $\mathrm{K}_{2} \mathrm{SiO}_{3}$ :}

The $3^{\text {rd }}$ experiment was planned to study the effect of the foliar application with potassium silicate $\mathrm{K}_{2} \mathrm{SiO}_{3}$ as a chemical inducers on tomato plants against the whitefly, B. tabaci. Three treatments were arranged in randomized complete block design with four replicates $\left(50 \mathrm{~m}^{2}\right.$ per each) as follow:

1- $0 \mathrm{ppm}$ potassium silicate (tab water spray) (control)

2- $200 \mathrm{ppm}$ potassium silicate

3- $400 \mathrm{ppm}$ potassium silicate

The treatments were applied (sprayed) by knapsack sprayer equipment (CP3) at the rate of 200 liter per feddan. Treatment of tomato plants repeatedly at byweekly intervals, the spraying and sampling were started 15 days post-planting and continue up to the end of the season (weekly10 leaflets were picked from each replicate). During the growing seasons, all the recommended agriculture practices were performed as usual. No pesticides were used throughout the experiment.

The diurnal activity or circadian rhythm of the whitefly, B. tabaci:

The objective of this experiment was to study the diurnal activity or circadian rhythm of the whitefly adults in tomato plants. The yellow sticky traps $(20 \times 15 \mathrm{~cm})$ were used in this experiment. Ten traps were placed at $5 \mathrm{~m}$ distances and hung at $50 \mathrm{~cm}$ above the ground levels. The traps were inspected at 2 hours intervals from 8 am to $8 \mathrm{pm}$ in the summer plantation and from 7 am to $5 \mathrm{pm}$ in the nili plantation (the traps were hung 2 hours before the $1^{\text {st }}$ inspection). The captured adults of $B$. tabaci were counted and recorded. The experiment was performed in the Friday from each week for 6 weeks in summer and nili plantations of the two consecutive seasons 2019 and 2020.

Field performance of insecticides treatments against nymph stage of whitefly:

This experiment was carried out in the summer plantation of tomato plants during the two successive seasons 2019 and 2020. The experiment was laid out in a randomized complete block design (RCBD) with four replications for each treatment $\left(50 \mathrm{~m}^{2}\right.$ each). The tested insecticides (Table 1) were applied by a manual knapsack sprayer (CP3) at the recommended field rate (200 liters 
Table 1. The active ingredient, trade name, formulations and recommended rate of the tested insecticide

\begin{tabular}{|c|c|c|c|c|}
\hline $\begin{array}{l}\text { Active } \\
\text { ingredient }\end{array}$ & $\begin{array}{l}\text { Trade } \\
\text { name }\end{array}$ & $\begin{array}{c}\% \text { and } \\
\text { formulation }\end{array}$ & Manufacturer & $\begin{array}{l}\text { Recommended } \\
\text { rates }\end{array}$ \\
\hline Acetamiprid & Mospilan $^{\circledR}$ & $20 \% \mathrm{SP}$ & $\begin{array}{l}\text { Nippon Soda Chemical Industry } \\
\text { Co. Ltd. }\end{array}$ & $25 \mathrm{mg} \mathrm{L}^{-1}$ \\
\hline Thiamethoxam & Actara ${ }^{\circledR}$ & $25 \% \mathrm{WDG}$ & Syngenta Agro & $50 \mathrm{mg} \mathrm{L}^{-1}$ \\
\hline Pyriproxyfen & Admiral $^{\circledR}$ & $10 \% \mathrm{EC}$ & Sumitomo Chemical Co. Ltd & $75 \mathrm{ml} / 100$ liter \\
\hline Buprofezin & Applaud $^{\circledR}$ & $25 \% \mathrm{SC}$ & Shaanxi Dideu Medichem Co. Ltd & $50 \mathrm{~mL} / 100 \mathrm{~L}^{-1}$ \\
\hline Sulfoxaflor & Closer $^{\circledR}$ & $24 \% \mathrm{SC}$ & DowAgro Sciences Co., Ltd & $100 \mathrm{~cm} /$ Fadden \\
\hline Dinotefuran & Ochin $^{\circledR}$ & $20 \% \mathrm{SG}$ & Mitsui Chemicals & $50 \mathrm{mg} \mathrm{L}^{-1}$ \\
\hline
\end{tabular}

*The used recommended rates were determined based on the recommendations of Egyptian Ministry of Agriculture

per feddan), while control plots were sprayed by water only. All the agricultural practices were applied as usual. The blocks were separated from each other the by untreated two rows. The samples taken before treatment, $1,4,7$ and 14 days post treatment (randomly ten leaflet of each plot). The reduction percentages of numbers of $B$. tabaci nymphs were calculated according to the equation of Henderson and Tilton's (1955):

Reduction $(\%)=(1-(\mathrm{Ma} * \mathrm{Mc} / \mathrm{Mb} * \mathrm{Md})) * 100$

Where:

$\mathrm{Ma}=$ mean numbers of $B$. tabaci nymphs in treatment after application

$\mathrm{Mc}=$ mean number of $B$. tabaci nymphs in control before application

$\mathrm{Mb}=$ mean number of $B$. tabaci nymphs in treatment before application

$\mathrm{Md}=$ mean number of $B$. tabaci nymphs in control after application

\section{Statistical Analysis}

All the data were statistically analyzed and expressed as mean values \pm standard error of the mean (SEM). The least significant differences (LSD) were calculated using the Student-Newman-Keuls (SNK) method at probability level of 0.05 SAS (2016).

\section{RESULTS AND DISCUSSION}

\section{Results}

Effect of plant spacing of tomato plants on the population density of $B$. tabaci:
Data presented in Figs. 1 and 2 show the effect of plant spacing on the density of $B$. Tabaci on tomato plants under open field conditions. The mean numbers of $B$. tabaci nymphs increased by decreasing planting space in both of the plantation dates throughout the two investigated seasons. As a mean of the whole season, the highest level of infestation with B. tabaci nymphs was occurred on tomato which plants sown at the shortest space $(20 \mathrm{~cm}$ between plants) with mean numbers of 64.55 and 36.51 nymphs/10 leaflets in summer and nili plantation, respectively during the $1^{\text {st }}$ season, 2019. In the $2^{\text {nd }}$ season, 2020 these means recorded 98.052 and 45.92 nymphs/10 leaflets in summer and nili plantation, respectively. The tomato plants which sown at $30 \mathrm{~cm}$ and $40 \mathrm{~cm}$ plant spacing were recorded intermediate infestation rates. At $30 \mathrm{~cm}$ spacing, (as a whole seasonal mean) general means of 47.91 and 77.7 nymphs/10 leaflets were recorded in the summer plantation and 22.71 and 32.16 nymphs/10 leaflets in the nili plantation during the two successive seasons 2019 and 2020, respectively . Concerning the plants sown at $40 \mathrm{~cm}$, these means decreased to 36.76 and 18.86 in the $1^{\text {st }}$ season, and 55.48 and 24.14 in the $2^{\text {nd }}$ season in summer and nili plantation, respectively. The lowest population densities of $B$. tabaci nymphs were recorded on tomato plants planted at the longest space $(50 \mathrm{~cm}$ between plants) with mean numbers of (28.13 and 16.25 nymphs/10 leaflets and 44.28 and 21.18 nymphs/10 leaflets) in the two plantation dates throughout the two successive seasons, respectively. 


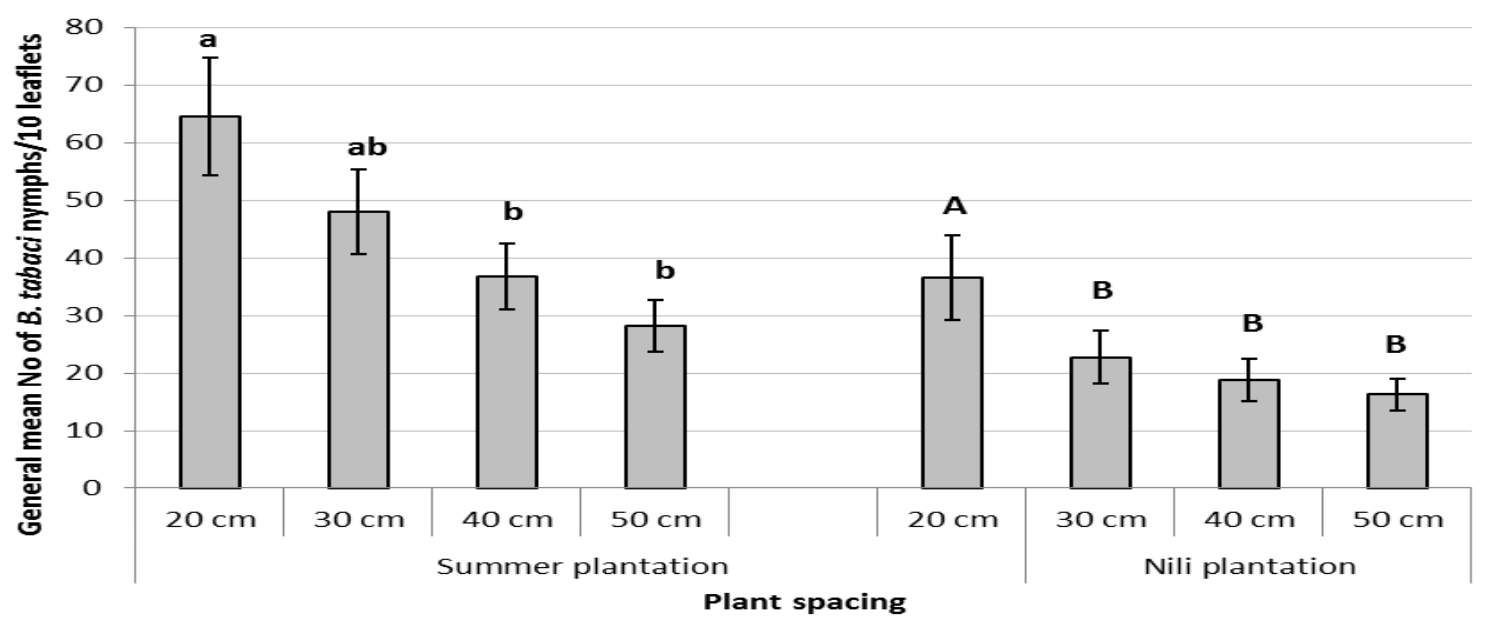

Fig. 1. The whole seasonal means of population density $( \pm$ SE) of Bemisia tabaci on tomato plants sown at different plant spacing in the $1^{\text {st }}$ season, 2019. $(F=4.706$, L.S.D. $=20.43065$ for summer plantation; $F=3.413$, L.S.D.= 13.76085 for nili plantation)

Bars with the same letter(s) are not significantly different at $P>0.05$, lower cases for summer and upper cases for nili plantation)

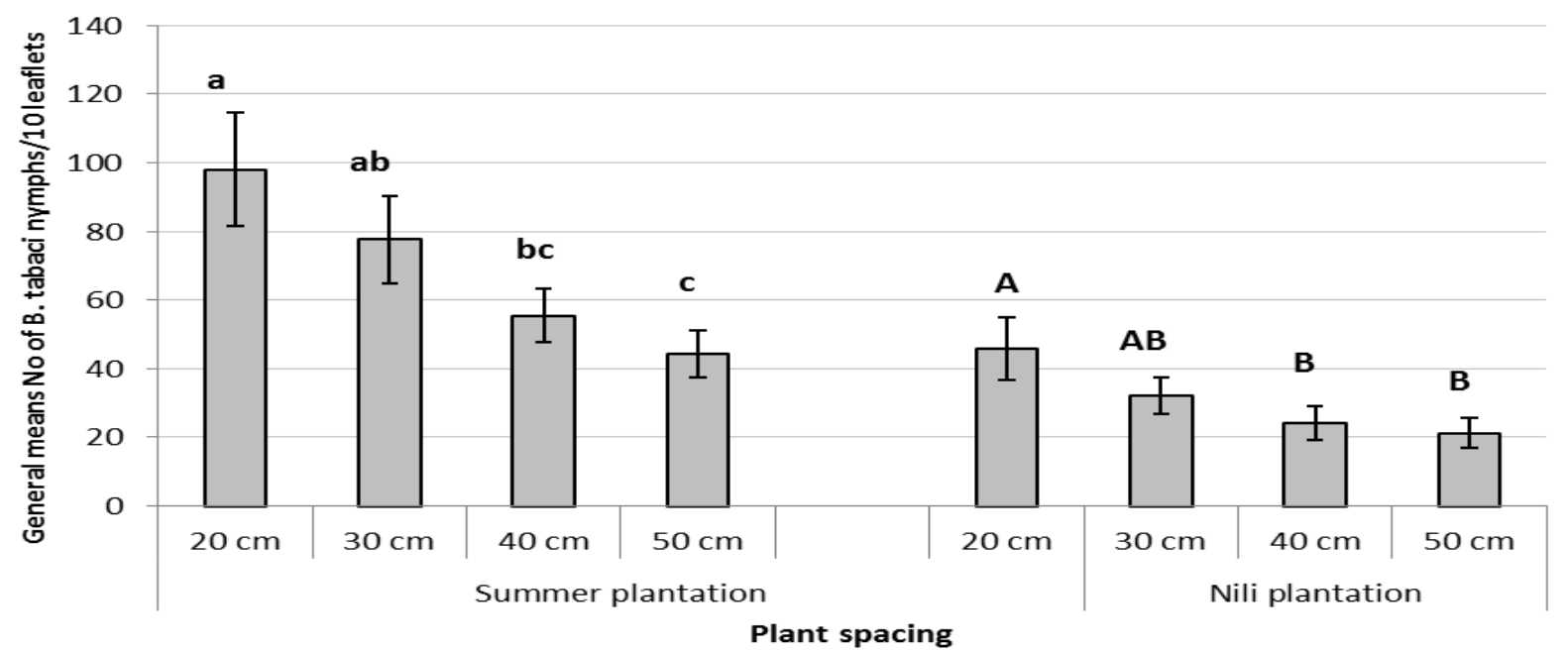

Fig. 2. The whole seasonal means of population density (means $\pm \mathrm{SE}$ ) of Bemisia tabaci on tomato plants sown at different plant spacing in the 2 nd season 2020. $(F=4.203$, L.S.D. $=32.97975$ for summer plantation; $F=3.185$, L.S.D.= 17.47785 for summer plantation)

Bars with the same letter(s) are not significantly different at $P>0.05$, lower cases for summer and upper cases for nili plantation) 
Effect of different combination of chemical fertilizers:

Data shown in Fig. 3 and 4 clearly demonstrated that nitrogen fertilizer was the most important factor affecting the population density of $B$. tabaci. The results also confirm that there is a positive correlation between population densities of $B$. tabaci and levels of nitrogen fertilizer on tomato plants. In summer plantation the general means of population density of $B$. tabaci nymphs increased from 47.49/ 10 leaflet to $78.67 / 10$ leaflet and from 69.99/10 leaflet to $91.5 / 10$ leaflet when the nitrogen fertilizers increase from $120 \mathrm{~N}$ : P: K to $180 \mathrm{~N}$ : P: $\mathrm{K}$ ( $150 \%$ of recommended nitrogen rate) in 2019 and 2020 respectively. Similar results were obtained in the nili plantation whereas the population density of $B$. tabaci significantly increased from $23.45 / 10$ leaflet to 35.88 / 10 leaflet and from 31.42/10 leaflet to 46.62 / 10 leaflet in 2019 and 2020, respectively. On the other hand, tomato plants which fertilized with $60 \mathrm{~N}$ : $50 \mathrm{P}: 100 \mathrm{~K}$ ratio (50\% of recommended nitrogen rate) had a lower density of $B$. tabaci nymphs (30.47 and 55.74 nymphs /10 leaflets in summer plantation and 15.83 and 25.5/ 10 leaflets in nili plantation during the two seasons, respectively) compared with the tomato plant treated with the recommended rates.

The effect of different rates of potassium fertilizers on B. tabci was the second noticed important effect. The tomato plants which fertilized with $\mathrm{N}$ : $\mathrm{P}: 1.5 \mathrm{~K}$ ratios (150\% of recommended potassium rate) infested with low densities of $B$. tabaci nymphs, whereas the general means of population density of $B$. tabaci nymphs recorded 29.29 and 13.34 nymphs /10 leaflets in the summer and nili plantations during the $1^{\text {st }}$ season. The statistical analysis of the obtained results revealed that the different rates of phosphorus fertilizers on tomato plant had the least effect on the population density of $B$. tabaci compared with nitrogen and/or potassium fertilizers.

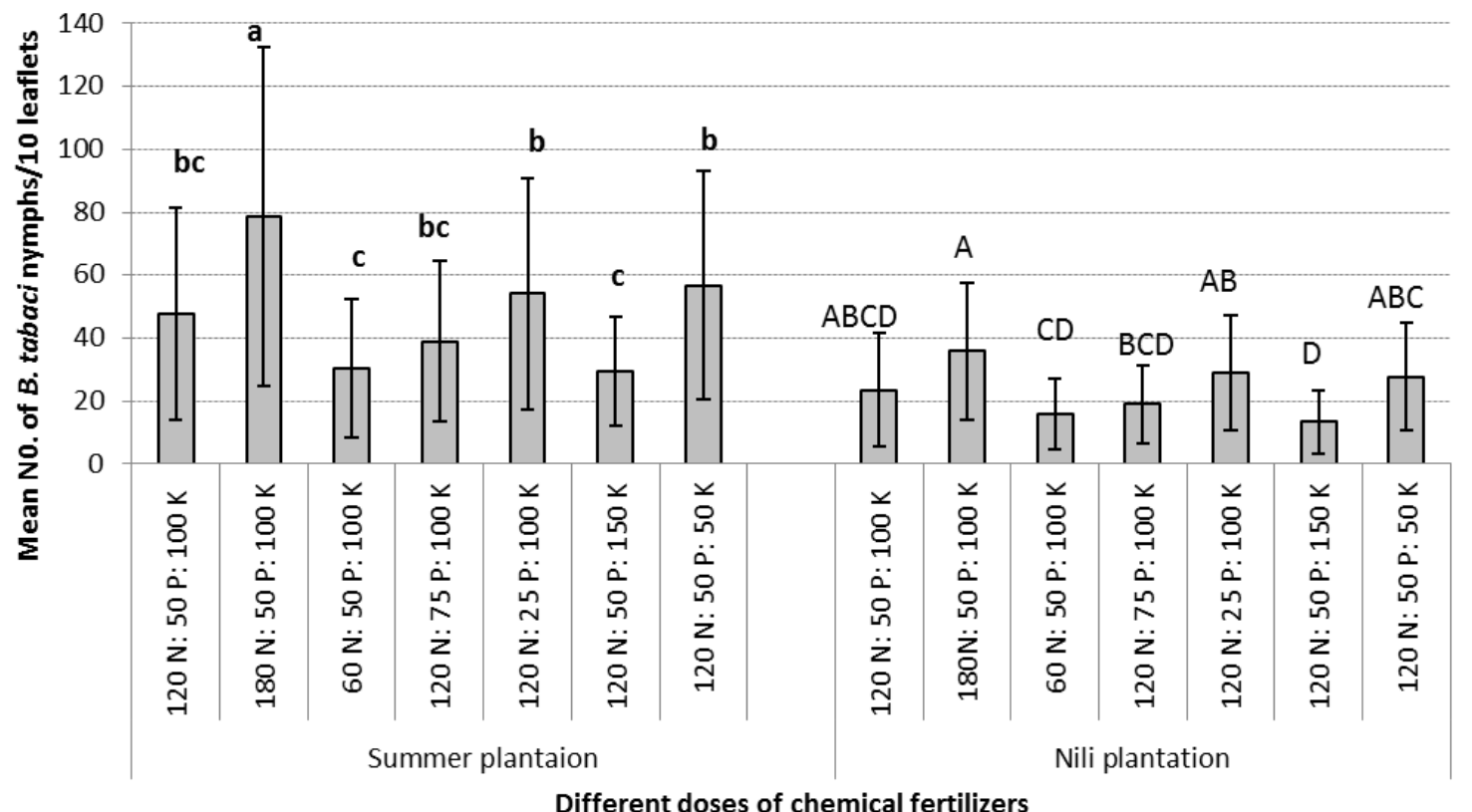

Different doses of chemical fertilizers

Fig. 3. The whole seasonal means of population density (means \pm SD) of Bemisia tabaci on tomato fertilized with different combinations of chemical fertilizers in the 1st season 2019. $(F=4.892$, L.S.D. $=21.8832$ for summer plantation; $F=5.272$, L.S.D.= 12.75765 for nili plantation)

Bars with the same letter(s) are not significantly different at $P>0.05$, lower cases for summer and upper cases for nili plantation) 


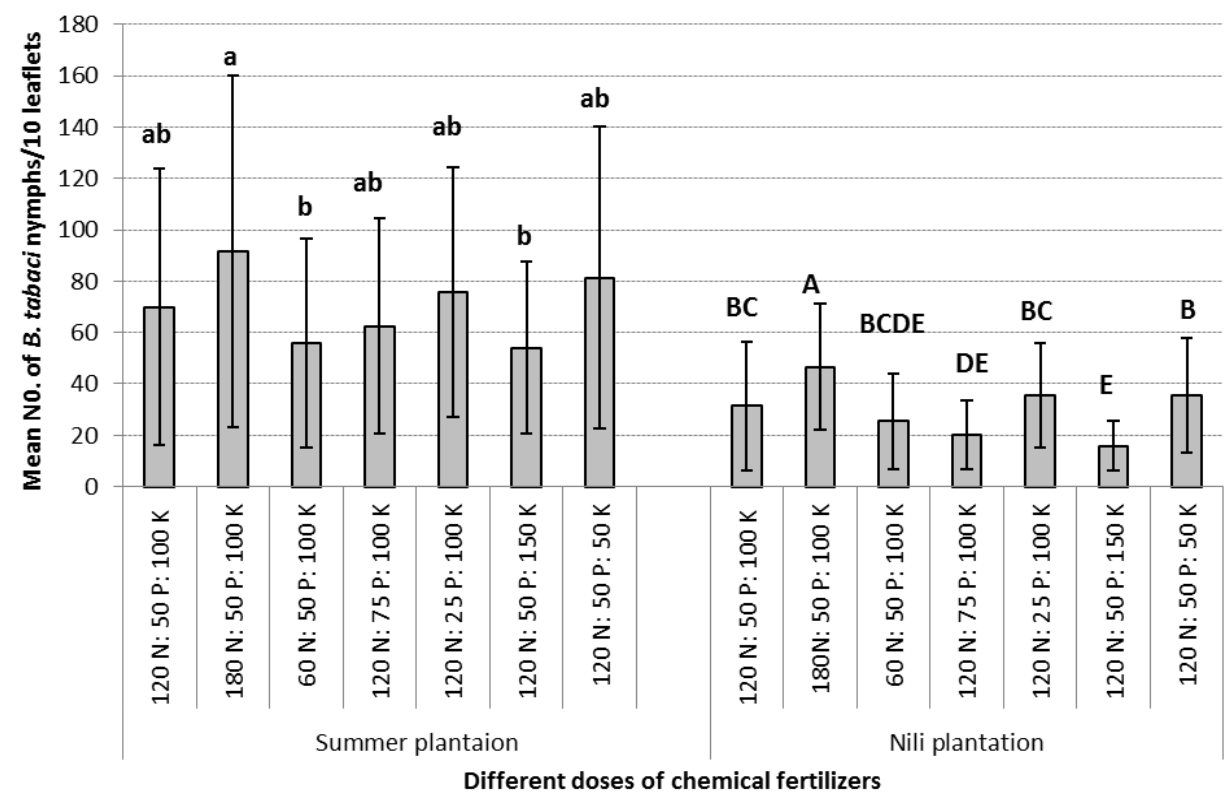

Fig. 4. The whole seasonal means of population density (means \pm SD) of Bemisia tabaci on tomato fertilized with different combinations of chemical fertilizers in the 2 nd season $2020 .(F=1.409$, L.S.D. $=32.50065$ for summer plantation; $F=4.724$, L.S.D.= 10.3209 for nili plantation)

Bars with the same letter(s) are not significantly different at $P>0.05$, lower cases for summer and upper cases for nili plantation)

As shown in Figs. 5 and 6, throughout growing season of tomato plants, the treatment with potassium silicate as a foliar spray (400 ppm) lead to significantly decreasing in the density of B. tabaci in the nili plantation and insignificantly decreasing in summer plantation. These results were repeated in both seasons of study, 2019 and 2020. The high density of B. tabaci in summer plantation than nili plantation might be the reason of the insignificantly in the decreasing of $\mathrm{B}$. tabaci in the summer plantation.

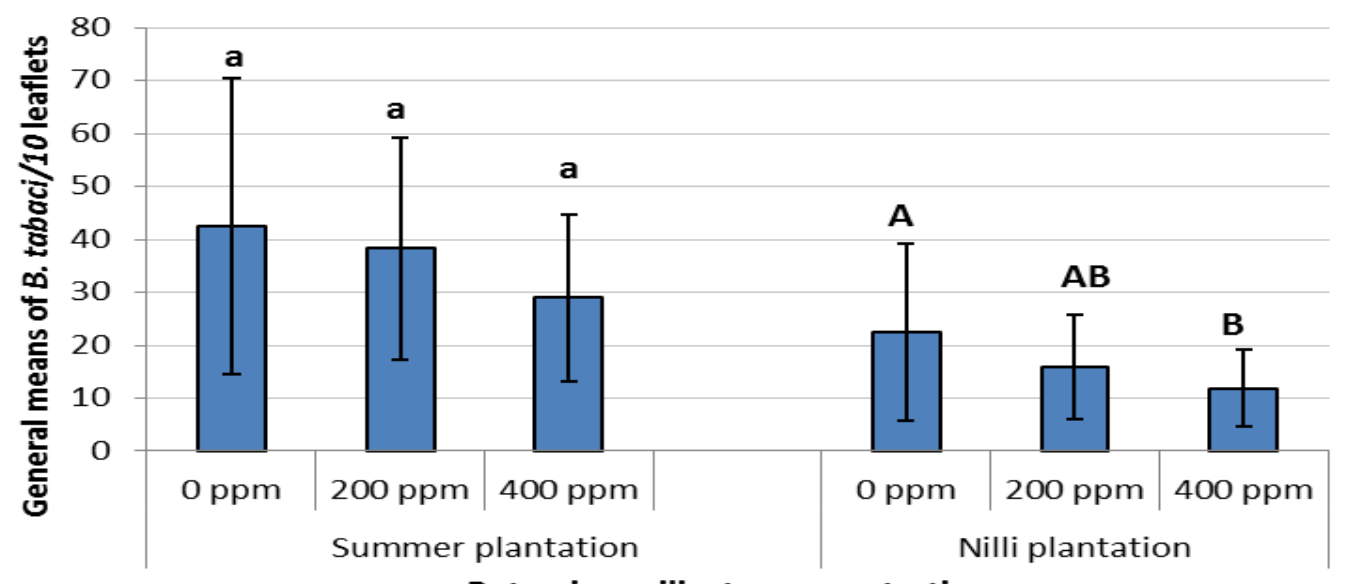

Potassium silicate concentrations

Fig. 5. The whole seasonal means of population density $( \pm$ SD) of Bemisia tabaci on tomato treated with potassium silicate in the 1st season 2019. $(F=1.846$, L.S.D.= 14.3732 for summer plantation; $F=3.744$, L.S.D.= 8.03325 for nili plantation)

Bars with the same letter(s) are not significantly different at $P>0.05$, lower cases for summer and upper cases for nili plantation) 


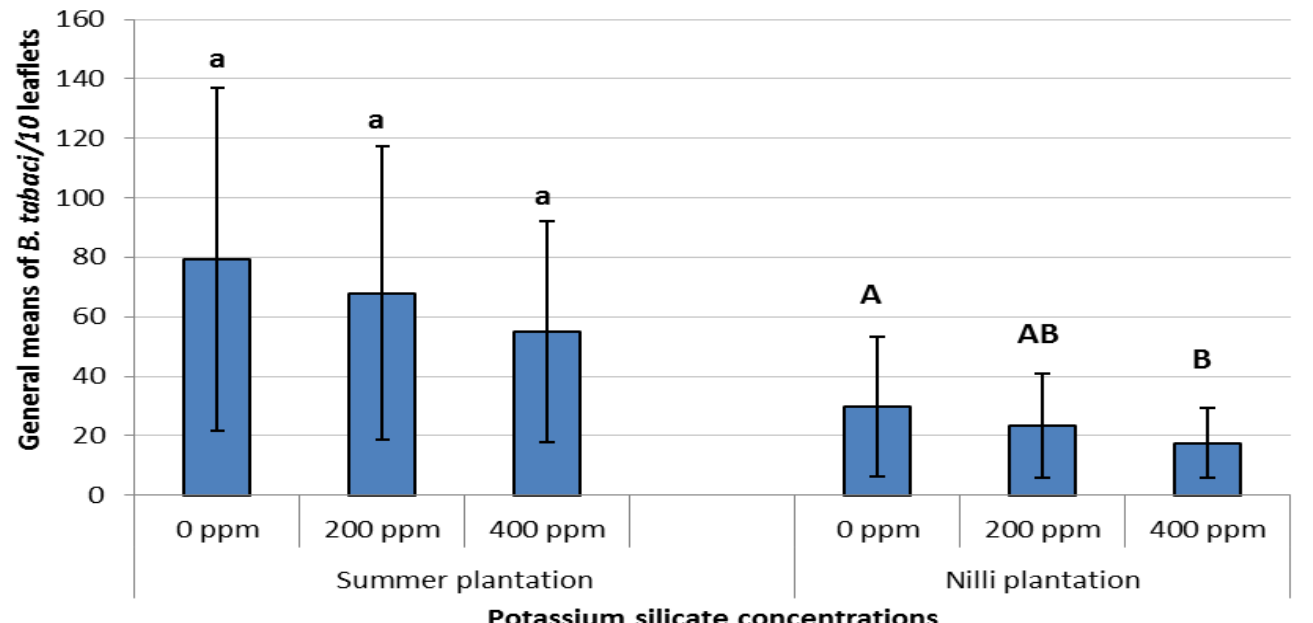

Fig. 6. The whole seasonal means of population density $( \pm$ SD) of Bemisia tabaci on tomato treated with potassium silicate in the $2^{\text {nd }}$ season 2020. $(F=1.179$, L.S.D. $=31.782$ for summer plantation; $F=2.164$, L.S.D. $=11.8658$ for nili plantation)

Bars with the same letter(s) are not significantly different at $P>0.05$, lower cases for summer and upper cases for nili plantation)

The diurnal activity or circadian rhythm of the whitefly, Bemisia tabaci:

The mean numbers of $B$. tabaci collected at different seven times of the day (in summer plantation) and/or five times (nili plantation) during the day are shown in Figs 7 and 8. Significantly greater numbers of adults of $B$. tabaci were collected at 10:00 am and 11:00 am in summer and nili plantations, respectively compared with the other different time of the day. In summer plantation, the number of adults decreased gradually up to the next peak which recorded at 4:00 pm, while in nili plantation the number of adults decreased gradually up to completely disappeared in the yellow trap. These results are repeated in the two successive seasons 2019 and 2020. The results also revealed that the circadian rhythms of whiteflies were different in the different planting dates.

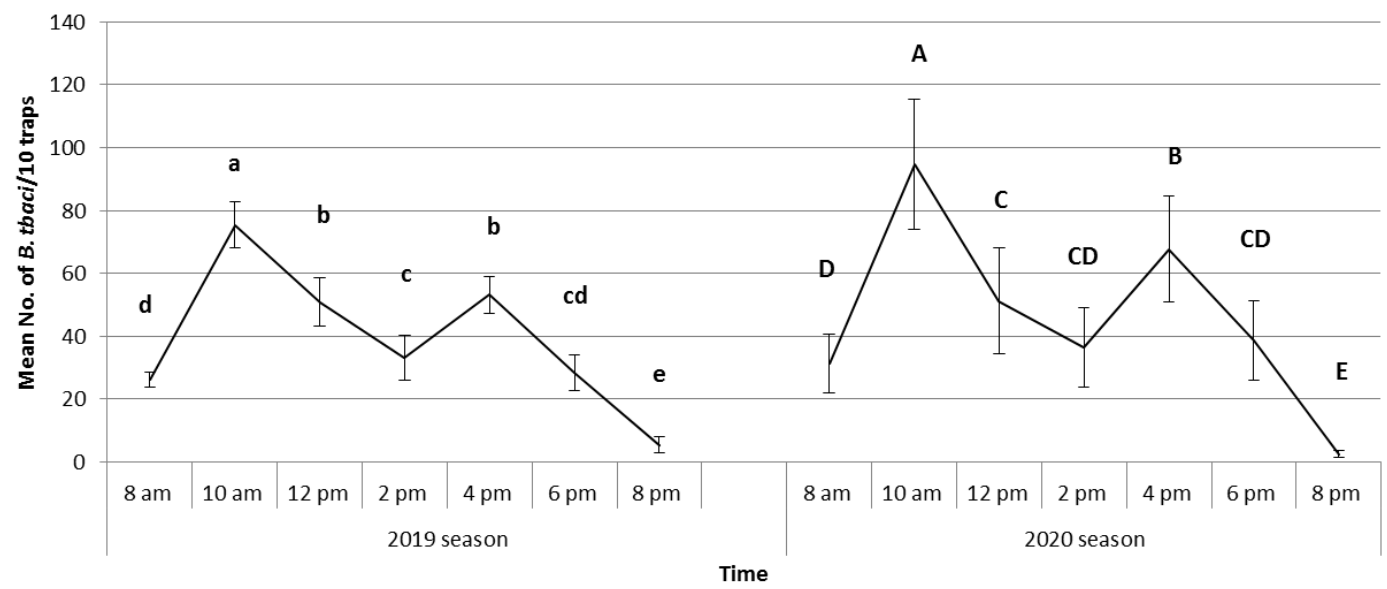

Fig. 7. The means of population density (means \pm SD) of Bemisia tabaci on tomato plants at different day hours in the summer plantation of 2019. and 2020 seasons. $(F=90.627$, L.S.D. $=6.85015$ for 2019 season; $F=25.708$, L.S.D.= 16.53445 for 2020 season)

Bars with the same letter(s) are not significantly different at $\mathbf{P}>\mathbf{0 . 0 5}$, lower cases for summer and upper cases for nili plantation) 


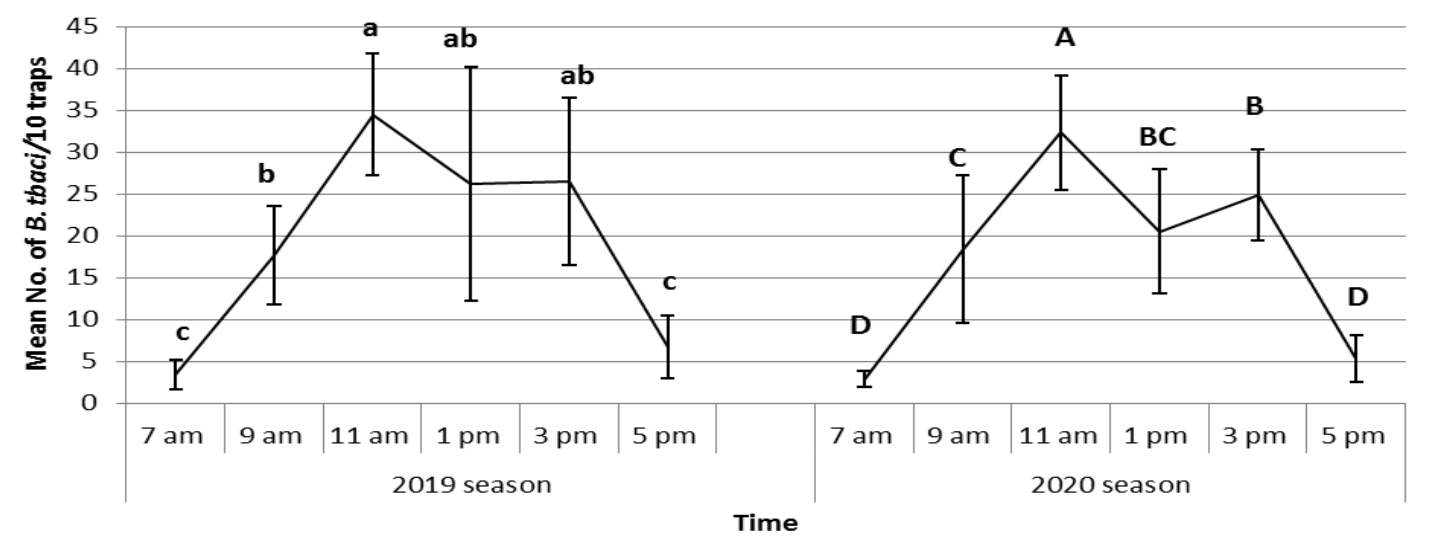

Fig. 8. The means of population density (means \pm SD) of Bemisia tabaci on tomato plants at different day hours in the nili plantation of 2019.and 2020 seasons. $(F=13.435$, L.S.D. $=9.63175$ for 2019 season; $F=21.252$, L.S.D.= 7.1241 for 2020 season)

Bars with the same letter(s) are not significantly different at $\mathbf{P}>0.05$, lower cases for summer and upper cases for nili plantation)

Field evaluation of different selected insecticides against nymphs of $B$. tabaci

Results shown in Tables (2-5) revealed that, all the tested insecticide achieved considerable reduction percentages in $B$. tabaci nymphs during the two seasons, 2019 and 2020. During 2019 season, sulfoxaflor achieved the highest efficiency, gave the following reduction percentages $(93.7,94.75,88.85$ and $83.62 \%$ after 1, 4, 7 and 14 days, respectively) with general mean $90.23 \%$ and $(95.97,97.51,92.99$ and $86.88 \%$ after 1,4 , 7 and 14 days, respectively) with general mean 93.34 after $1^{\text {st }}$ and $2^{\text {nd }}$ spray, respectively. The insecticide thiamethoxam came in the $2^{\text {nd }}$ rank giving $(80.55,87.65$, 91.1 and $81.94 \%$ after $1,4,7$ and $14 \%$ days, respectively) with a general mean of $85.31 \%$ and (80.92, $84.14,80.38$ and $77.58 \%$ after $1,4,7$ and 14 days, respectively) with a general mean of $80.75 \%$ after $1^{\text {st }}$ and $2^{\text {nd }}$ spray, respectively. In the $3^{\text {rd }}$ place comes the insecticides acetamiprid which achieved (83.93, 89.31, 83.72 and $77.18 \%$ after $1,4,7$ and 14 days, respectively) with a general mean of $83.54 \%$ and $(74.66,83.2,83.01$ and $67.25 \%$ after $1,4,7$ and 14 days, respectively) with a general mean of $77.03 \%$ after $1^{\text {st }}$ and $2^{\text {nd }}$ spray, respectively. The insecticides pyriproxyfen gave reduction percentages of $(64.24,71.73,81.57$ and $76.93 \%$ after $1,4,7$ and 14 days, respectively) with general mean $73.62 \%$ and $(63.67,73.46,74.83$ and 66.76 $\%$ after 1, 4, 7 and 14 days, respectively) with a general mean of $69.98 \%$ after $1^{\text {st }}$ and $2^{\text {nd }}$ spray, respectively. The reduction percentages of buprofezin insecticide recorded (65.77, 75.52, 72.36 and $64.78 \%$ after $1,4,7$ and 14 days, respectively) with general mean $69.61 \%$ and (66.81, 71.19, 62.42 and 63.15) with general mean $65.89 \%$ after $1^{\text {st }}$ and $2^{\text {nd }}$ spray, respectively. Dinotefuran insecticide achieved the least efficacy, giving the following reduction percentages $(64.02,60.84,57.11$ and $54.14 \%$ after $1,4,7$ and 14 days, respectively) with a general mean of $59.03 \%$ and $(68.85,64.99,58.41$ and $51.22 \%$ after $1,4,7$ and 14 days, respectively) with a general mean of $60.87 \%$ after $1^{\text {st }}$ and $2^{\text {nd }}$ spray, respectively. In 2020 season, similar results were obtained whereas the reduction percentages of the tested insecticides according to its efficiency against nymphs of B. tabaci can be arranged discerningly as follows: sulfoxaflor, thiamethoxam, acetamiprid, pyriproxyfen, buprofezin and dinotefuran with general means of 94.17, $83.52,83.06,76.57,66.24$ and $56.97 \%$ after the $1^{\text {st }}$ spray and $89.19,83.08,80.78,70.84,67.91,62.07 \%$ after the $2^{\text {nd }}$ spray, respectively. 
Table 2. Effect of six insecticides on nymphs of Bemisia tabaci on tomato plants under field conditions during 2019 season (after $1^{\text {st }}$ spray)

\begin{tabular}{|c|c|c|c|c|c|}
\hline \multirow{2}{*}{ Insecticides } & \multicolumn{4}{|c|}{ Days post treatment } & \multirow{2}{*}{$\begin{array}{c}\text { General } \\
\text { means } \pm \text { SD }\end{array}$} \\
\hline & 1 & 4 & 7 & 14 & \\
\hline Acetamiprid & $83.93 \pm 5.29^{\mathbf{b c}}$ & $89.31 \pm 3.43^{\text {ab }}$ & $83.72 \pm 4.19^{\mathbf{b c}}$ & $77.18 \pm 4.45^{\mathbf{b}}$ & $83.54 \pm 5.93^{b}$ \\
\hline Sulfoxaflor & $93.7 \pm 2.32^{\mathrm{a}}$ & $94.75 \pm 1.14^{\mathrm{a}}$ & $88.85 \pm 2.78^{\mathbf{a b}}$ & $83.62 \pm 4.07^{\mathrm{a}}$ & $90.23 \pm 5.2^{\mathrm{a}}$ \\
\hline Dinotefuran & $64.02 \pm 6.99^{d}$ & $60.84 \pm 6.16^{d}$ & $57.11 \pm 5.52^{\mathrm{e}}$ & $54.14 \pm 5.85^{d}$ & $59.03 \pm 6.72^{\mathrm{e}}$ \\
\hline Pyriproxphene & $64.24 \pm 6.75^{d}$ & $71.73 \pm 6.26^{\mathrm{c}}$ & $81.57 \pm 3.67^{\mathrm{c}}$ & $76.93 \pm 3.19^{b}$ & $73.62 \pm 8.12^{\mathrm{cd}}$ \\
\hline Thiamethoxam & $80.55 \pm 7.14^{\mathrm{c}}$ & $87.65 \pm 3.81^{\mathbf{b}}$ & $91.1 \pm 2.73^{\mathrm{a}}$ & $81.95 \pm 3.93^{\mathrm{ab}}$ & $85.31 \pm 6.9^{\mathbf{b}}$ \\
\hline Buprofezin & $65.77 \pm 5.23^{d}$ & $75.52 \pm 4.99^{c}$ & $72.36 \pm 1.59^{d}$ & $64.78 \pm 1.38^{\mathrm{c}}$ & $69.61 \pm 5.73^{d}$ \\
\hline $\mathrm{F}$ value & 18.198 & 30.323 & 48.263 & 31.756 & 53.384 \\
\hline L. S. D. & 8.70565 & 6.9029 & 5.39535 & 6.0077 & 4.47115 \\
\hline
\end{tabular}

The means superscripted with the same alphabets in the same columns do not significantly differ from each other as per least significant difference test $(\mathrm{p} \geq 0.05)$

Table 3. Effect of six insecticides on nymphs of Bemisia tabaci on tomato plants under field conditions during 2019 season (after 2nd spray)

\begin{tabular}{|c|c|c|c|c|c|}
\hline \multirow[t]{2}{*}{ Insecticides } & \multicolumn{4}{|c|}{ Days post treatment } & \multirow{2}{*}{$\begin{array}{c}\text { General means } \\
\pm \text { SD }\end{array}$} \\
\hline & 1 & 4 & 7 & 14 & \\
\hline Acetamiprid & $74.66 \pm 5.76^{\mathrm{bc}}$ & $83.2 \pm 7.63^{\mathrm{b}}$ & $83.01 \pm 3.47^{\mathbf{b}}$ & $67.25 \pm 2.39^{c}$ & $77.03 \pm 8.28^{b}$ \\
\hline Sulfoxaflor & $95.97 \pm 1.55^{\mathrm{a}}$ & $97.51 \pm 3.85^{\mathrm{a}}$ & $92.99 \pm 2.57^{\mathrm{a}}$ & $86.88 \pm 5.63 \mathrm{a}$ & $93.34 \pm 5.36^{\mathrm{a}}$ \\
\hline Dinotefuran & $68.85 \pm 8.03^{\mathrm{cd}}$ & $64.99 \pm 5.15^{\mathrm{d}}$ & $58.41 \pm 5.92^{d}$ & $51.22 \pm 3.99^{d}$ & $60.87 \pm 8.74^{d}$ \\
\hline Pyriproxphene & $63.67 \pm 7.85^{\mathrm{d}}$ & $73.46 \pm 6.43^{c}$ & $74.83 \pm 6.33^{c}$ & $66.76 \pm 8.18^{c}$ & $69.68 \pm 8.05^{\mathrm{c}}$ \\
\hline Thiamethoxam & $80.92 \pm 3.01^{b}$ & $84.14 \pm 6.27^{b}$ & $80.38 \pm 4.79^{\mathbf{b c}}$ & $77.58 \pm 7.37^{\mathbf{b}}$ & $80.75 \pm 5.56^{\mathbf{b}}$ \\
\hline Buprofezin & $66.81 \pm 7.5^{\mathrm{cd}}$ & $71.19 \pm 6.59^{\mathrm{cd}}$ & $62.42 \pm 7.02^{\mathrm{d}}$ & $63.15 \pm 6.75^{\mathrm{c}}$ & $65.89 \pm 7.2^{\text {cd }}$ \\
\hline F value & 14.987 & 14.482 & 24.544 & 16.373 & 40.864 \\
\hline L. S. D. & 9.1346 & 9.0686 & 7.8174 & 9.00055 & 5.1387 \\
\hline
\end{tabular}

The means superscripted with the same alphabets in the same columns do not significantly differ from each other as per least significant difference test $(\mathrm{p} \geq 0.05)$

Table 4. Effect of six insecticides on nymphs of Bemisia tabaci on tomato plants under field conditions during 2020 season (after 1st spray)

\begin{tabular}{cccccc}
\hline \multirow{2}{*}{ Insecticides } & \multicolumn{5}{c}{ Days post treatment } \\
\cline { 2 - 5 } & $\mathbf{1}$ & $\mathbf{4}$ & $\mathbf{7}$ & $\mathbf{1 4}$ & \\
\cline { 2 - 5 } Acetamiprid & $81.08 \pm 3.37^{\mathbf{b}}$ & $88.43 \pm 2.33^{\mathbf{b}}$ & $85.2 \pm 3^{\mathbf{b}}$ & $77.51 \pm 2.45^{\mathbf{b}}$ & $83.06 \pm 4.95^{\mathbf{b}}$ \\
Sulfoxaflor & $95.41 \pm 1.44^{\mathbf{a}}$ & $97.15 \pm 1.86^{\mathbf{a}}$ & $93.41 \pm 1.91^{\mathbf{a}}$ & $90.72 \pm 2.71^{\mathbf{a}}$ & $94.17 \pm 3.07^{\mathbf{a}}$ \\
Dinotefuran & $59.89 \pm 6.08^{\mathbf{c}}$ & $57.02 \pm 2.67^{\mathbf{e}}$ & $59.13 \pm 5.75^{\mathbf{e}}$ & $51.85 \pm 4^{\mathbf{d}}$ & $56.97 \pm 5.4^{\mathbf{e}}$ \\
Pyriproxphene & $76.82 \pm 3^{\mathbf{b}}$ & $78.3 \pm 3.68^{\mathbf{c}}$ & $80.24 \pm 2.68^{\mathbf{c}}$ & $70.94 \pm 4.3^{\mathbf{c}}$ & $76.57 \pm 4.71^{\mathbf{c}}$ \\
Thiamethoxam & $79.07 \pm 3.1^{\mathbf{b}}$ & $84.04 \pm 2.89^{\mathbf{b}}$ & $90.11 \pm 1.09^{\mathbf{a}}$ & $80.84 \pm 2.36^{\mathbf{b}}$ & $83.52 \pm 4.88^{\mathbf{b}}$ \\
Buprofezin & $61.66 \pm 6.63^{\mathbf{c}}$ & $66.46 \pm 4.45^{\mathbf{d}}$ & $69.92 \pm 1.23^{\mathbf{d}}$ & $66.92 \pm 5.16^{\mathbf{c}}$ & $66.24 \pm 5.26^{\mathbf{d}}$ \\
F value & 37.278 & 90.152 & 73.028 & 54.041 & 125.063 \\
\hline L. S. D. & 6.4446 & 4.60535 & 4.5213 & 5.3748 & 3.3529 \\
\hline
\end{tabular}

The means superscripted with the same alphabets in the same columns do not significantly differ from each other as per least significant difference test $(\mathrm{p} \geq 0.05)$ 
Table 5. Effect of six insecticides on nymphs of Bemisia tabaci on tomato plants under field conditions during 2020 season (after 2nd spray)

\begin{tabular}{cccccc}
\hline \multirow{2}{*}{ Insecticides } & \multicolumn{4}{c}{ Days post treatment } & General means \\
\cline { 2 - 5 } & 1 & 4 & 7 & 14 & \pm SD \\
\hline Acetamiprid & $78.93 \pm 4.38^{\mathbf{b c}}$ & $81.26 \pm 3.74^{\mathbf{b}}$ & $81.64 \pm 4.52^{\mathbf{b}}$ & $81.28 \pm 4.13^{\mathbf{b}}$ & $80.78 \pm 3.92^{\mathbf{b}}$ \\
Sulfoxaflor & $87.57 \pm 5.98^{\mathbf{a}}$ & $89.19 \pm 5.31^{\mathbf{a}}$ & $90.54 \pm 2.13^{\mathbf{a}}$ & $89.48 \pm 3.33^{\mathbf{a}}$ & $89.19 \pm 4.14^{\mathbf{a}}$ \\
Dinotefuran & $74.79 \pm 2.29^{\mathbf{c}}$ & $63.47 \pm 2.84^{\mathbf{d}}$ & $57.4 \pm 3.62^{\mathbf{d}}$ & $52.6 \pm 3.03^{\mathbf{d}}$ & $62.07 \pm 8.97^{\mathbf{d}}$ \\
Pyriproxphene & $67.06 \pm 5.9^{\mathbf{c d}}$ & $75.01 \pm 4.92^{\mathbf{c}}$ & $71.98 \pm 3.7^{\mathbf{c}}$ & $69.32 \pm 8.84^{\mathbf{c}}$ & $70.84 \pm 6.29^{\mathbf{c}}$ \\
Thiamethoxam & $83.46 \pm 3.41^{\mathbf{a b}}$ & $85.91 \pm 1.71^{\mathbf{a b}}$ & $85.23 \pm 2.12^{\mathbf{a b}}$ & $77.73 \pm 3.58^{\mathbf{b}}$ & $83.08 \pm 4.17^{\mathbf{b}}$ \\
Buprofezin & $61.54 \pm 10.57^{\mathbf{d}}$ & $83.31 \pm 3.4^{\mathbf{a b}}$ & $69.12 \pm 7.66^{\mathbf{c}}$ & $57.68 \pm 4.11^{\mathbf{d}}$ & $67.91 \pm 11.92^{\mathbf{c}}$ \\
F value & 10.714 & 23.176 & 30.792 & 33.420 & 32.760 \\
\hline L. S. D. & 8.64325 & 5.7194 & 6.5033 & 7.30585 & 5.06565 \\
\hline
\end{tabular}

The means superscripted with the same alphabets in the same columns do not significantly differ from each other as per least significant difference test $(\mathrm{p} \geq 0.05)$

\section{Discussion}

In an attempt to help in developing an integrated pest management program of the whitefly, B. tabaci, the present effort was made to study the effect of some factors on its density on tomato plants under the open field conditions. The results clearly show that the population density of whitefly, $B$. tabaci was significantly more abundant in the narrow spacing (20 $\mathrm{cm})$ than the other spaces $(30,40$ and $50 \mathrm{~cm}$ ). These results are in synchronized with those stated by Abd ElMalak and Salem (2002) who studied the effect of plant spacing of sweetpotato plants $(20,25$ and $30 \mathrm{~cm})$ on the population density of six arthropods include $B$. tabaci and found that the highest population densities were recorded in the shortest spacing. The present results also are in agreement with both of Emam et al. (2006) on their studies on sweetpea plants, Mohamed (2012) on his studies on cucumber plants and Momtaz, et al., (2018) on cotton plants who reported highest mean numbers of $B$. tabaci in the narrow plant spacing. The present results indicated that there are significantly increasing of population density of $B$. tabaci nymphs by increasing nitrogen fertilizer (from $120 \mathrm{~N}$ to $180 \mathrm{~N}$ ). These results are in harmony with the experiments of $\mathrm{Bi}$, et al., (2001) on cotton plants and Draz, et al., (2013) who found that increasing in nitrogen fertilizer affect the biological aspects of Bemisia argentifolii (lead to longer of adult longevity, higher survival rates and also increased of longest of reproductive periods). Also, Minkenberg and Ottenheim (1990) reported that the increasing of nitrogen in tomato leaves lead to greater rate of eggs laid per day and fecundity of B. tabaci. LU Zhong-xian, et al., (2007) attributed the positive effects on population density of the insect pests which feeding on plants treated with high rates of nitrogen fertilizer to the increasing of the soluble protein content. our results suggest that the increases of potassium fertilizer rates lead to reduction in the density of $\mathrm{B}$. tabaci in agreement with the results of Perrenound (1977) and AL-Khazraji, et al. (2018). Concerning the treatment with potassium silicate, our results in line with the results of Abbasi et al., (2020) who suggested that the foliar application with silicon sources for controling $B$. tabaci is effective and an eco-friendly approach.

The study of diurnal activity clearly shows that there are significant differences in the collected number of $B$. tabaci at different times of the day. Our results confirmed the results of Pan, et al. (2015) who found that the flight activity of whitefly, B. tabaci was low in near of both sunrise and sunset and increased in the other day hours. The current study revealed that during the day hours the whitefly, B. tabaci has two active peaks. In disagreement with this results, Bellows et al. (1988) found that the whitefly, B. tabaci showed a unimodal activity. In this study, the insecticide sulfoxaflor $\left(\mathrm{Closer}^{\circledR}\right)$ was the most effective insecticide among the six tested insecticides followed by thiamethoxam, acetamiprid, pyriproxphene, buprofezin and finally dinotefuran. Thus, our results are synchronized with that of Jahel, et al. (2017) who found that the insecticide sulfoxaflor was the most effective insecticide among Sulfoxaflor, Azadirachtin, Beauveria bassiana insecticides. Also, the present results are in agreement with Barrania and Abou-Taleb (2014) who tested five insecticides viz., pyriproxyfen, novaluron, thiamethoxam, imidacloprid, acetamiprid and chlorantraniliprole against immature stages of B. tabaci. They found that all tested insecticides were comparable against $B$. tabaci nymphs, and both of thiamethoxam and acetamiprid achieved the highest reduction percentage in two consecutive seasons. The present results show that the chitin synthesis inhibitors (pyriproxyfen and Buprofezin) were effective against $B$. tabaci nymphs in agreement with both of Lee et al., (2002) and Cutler et al., (2005) who found that the insect growth regulator, pyriproxyfen and novaluron were effective against immature stages of $B$. tabaci and relatively low effective against the adult stage. In general, the current results recommended to use sulfoxaflor or thiamethoxam insecticides or in a sequential treatment with chitin 
inhibitors, at the proper diurnal activity of $B$. tabaci to control the pest, beside the use appropriate plant spacing and the better rates of chemical fertilizers (NPK) in the IPM programs.

\section{REFERENCES}

Abbasi, A., M. Sufyan, M.J. Arif and S.T. Sahi. 2020. Effect of silicon on oviposition preference and biology of Bemisia tabaci (Gennadius) (Homoptera: Aleyrodidae) feeding on Gossypium hirsutum (Linnaeus). Int J. Pest Manag.1-11. https://doi.org/10.1080/09670874.2020.1802084

Abd El-Malak, V.S.G. and A.A. Salem. 2002. Influence of planting spaces and hybrid on the population of six arthropods attacking sweet potato plant. Annals Agric. Moshtohor. 40 (3):1797-1806.

AL-Khazraji, H.I., N.S. Abed, M.Z. AL-Mharib and S. ALDarraji. 2018. Effect of potassium fertilization and organic nutrient (Reef Amirich) in the population density of Bemisia tabaci (Genn.) and Thrips tabaci (L.) on cucumber. J. of Biodiversity and Environmental Sci. 12 (2): 11-18. https://innspub.net/jbes/effect-potassium-fertilizationorganic-nutrient-reef-amirich-population-density-bemisiatabaci-genn-thrips-tabaci-l-cucumber/

Aregbesola, O.Z., J.P. Legg, L. Sigsgaard, O.S. Lund, C. Rapisarda. 2019. Potential impact of climate change on whiteflies and implications for the spread of vectored viruses. J. of Pest Sci. 92:381-392.

https://doi.org/10.1007/s10340-018-1059-9

Barrania, A.A. and H.K. Abou-Taleb. 2014. Field efficiency of some insecticide treatments against whitefly, Bemisia tabaci, cotton aphid, Aphis gossypii and their associated predator, Chrysopa vulgaris, in cotton plants. Alex. J. Agric. Res. 59 (2): 105-111.

Bellows, T.S., T.M. Perring, K. Arakawa and C.A. Farrar. 1988. Patterns in diel flight activity of Bemisia tabaci (Homoptera: Aleyrodidae) in cropping systems in southern Califonia. Environmental Entomology. 17: 225-228.

https://doi.org/10.1093/ee/17.2.225

Bi, J.L., G.R. Ballmer, D.L. Hendrix, T.J. Henneberry and N.C. Toscano. 2001. Effect of cotton nitrogen fertilization on Bemisia argentifolii population and honeydew production. Entomol Exp Appl. 99: 25-36. https://doi.org/10.1046/j.1570-7458.2001.00798.x

Cutler, G.C., C.D. Scott-Dupree, J.H. Tolman and C.R. Harris. 2005. Acute and sublethal toxicity of Novaluron, a novel chitin synthesis inhibitor, to Leptinotarsa decemlineata (Coleoptera: Chrysomelidae). J. of Pest Management Sci. 61: 1060-1068. https://doi.org/10.1002/ps.1091

Draz, Kh.A.A., A.A.E. Darwish and R.M.M. Tabikha. 2013. Effect of different rates of nitrogen fertilizer on infestation level with piercing sucking insect Pests of tomato crop, Lycopersiconesculentum L. J. Agric. \& Env. Sci. Dam.Univ., Egypt. 12 (3):20-32.

Emam, A.K., M.F.A.H. Hega and M.A.M. Tantawy. 2006. Effect of planting space and date on the population densities of certain insect pests infesting sweetpea plants at Qalyobia Governorate. Ann. Agric. Sci. Moshtohor. 44 (1):299-308.
Firdaus, S., A. Heusden, N. Hidayati, E. Supena, R. Visser, B. Vosman. 2012. Resistance to Bemisia tabaci in tomato wild relatives. Euphytica. 187 (1): 31-45. 10.1007/s10681-0120704-2

Henderson, C.F. and E.W. Tilton. 1955. Tests with acaricides against the brown mite. J. Econ Entomol. 48: 157-161.

Idriss, M.H., F.A. El-Meniawi, I.A. Rawash and A.M. Soliman. 2015. Effects of different fertilization levels of tomato plants on population density and biometrics of the cotton whitefly, Bemisia tabaci (Gennadius) (Hemiptera: Sternorrhyncha: Aleyrodidae) under greenhouse conditions. Middle East J. of Applied Sci. 5 (3): 759-768. http://www.curresweb.com/mejas/mejas/2015/759-768.pdf

Jahel, M.K., Safaa M. H., A.A.Hafez, T.R. Abd El-Zahar and K. Kh. Elgizawy. 2017. Comparative efficacy of different insecticides against whitefly, Bemisia tabaci (Gennadius) (Homoptera: Aleyrodidae) on Tomato Plants. Middle East J. of Applied Sci. 07 (04): 786-793.

Jahn, G.C. 2004. Effect of soil nutrients on the growth, survival and fecundity of insect pests of rice: an overview and a theory of pest outbreaks with consideration of research approaches. Multitrophic interactions in Soil and Integrated Control. International Organization for Biological Control (IOBC) wprs Bulletin. 27 (1):115-122.

Jha, S.K. and M. Kumar. 2017. Effect of weather parameters on incidence of whitefly, Bemisia tabaci (Gennadius) on tomato. J. of Entomology and Zoology Studies. 5(6): 304306.

https://www.entomoljournal.com/archives/2017/vol5issue 6/PartE/5-5-89-519.pdf

Lee, Y. S., S. Y. Lee, E. C. Park, J. H. Kim and G. H. Kim. 2002. Comparative toxicities of pyriproxyfen and thiamethoxam against the sweetpotato whitefly, Bemisia tabaci (Homoptera: Aleyrodidae). J. Asia-Pacific Entomol. 5: $117-122$.

LU, Zhong-xian, YU Xiao-ping, Kong-luen HEONG, HU Cui. 2007. Effect of Nitrogen Fertilizer on Herbivores and Its Stimulation to Major Insect Pests in Rice. Rice Sci.14 (1) : 56-66.

Mohamed, M.A. 2012. Impact of planting dates, spaces and varieties on infestation of cucumber plants with whitefly, Bemisia tabaci (Genn.). The J. of Basic \& Applied Zoology. 65:17-20. http://dx.doi.org/10.1016/j.jobaz.2012.01.003

Mahmoud, M.A.A. 2017. Field performance of insecticides treatments against the immature and adult stages of whitefly on tomato plant. Alex. Sci. Exc. J. 38(3): 613-619. https://journals.ekb.eg/article_4053_6f8473e8cd96b4640c e6a419d76427f3.pdf

Minkenberg, O.P. and J.J. Ottenheim. 1990. Effect of leaf nitrogen content of tomato plants on preference and performance of a leafmining fly. Oecologia. 83: 291-298. https://link.springer.com/article/10.1007\%2FBF00317551

Momtaz, M. B., K. Yeasmin, M.R. Khatun and M. Ahmad. 2018. Impact of Plant Spacing on Population Dynamics of Sucking Pest of Cotton. J. Environ. Sci. \& Natural Resources. 11(1\&2):241-243 
Palumbo, J.C., N.C. Toscano, M.J. Blua, H.A.Yoshida. 2000. Impact of Bemisia whiteflies (Homoptera: Aleyrodidae) on Alfalfa growth, forage yield and quality. J. Econ. Entomol. 93(6): 1688-1694.

Pan P.L., Q. Xu and Y.Ch. Qin. 2015. Circadian rhythm and spatial distribution of mixed populations of two whitefly species on cucumber in greenhouses. African Entomology. 23(2): 306-313.

Perrenound, S. 1977. Potassium and plant health. International Potash Institute, Berne.

Perring T.M. 2001. The Bemisia tabaci species complex. Crop Protection. 20:725-737.

Polston, J.E., P. De Barro, L.M. Boykin. 2014. Transmission specificities of plant viruses with the newly identified species of the Bemisia tabaci species complex. Pest. Manag. Sci. 70:547-1552. https://doi.org/10.1002/ps.3738

Prado Maluta, N. K., J. R. S. Lopes, E. Fiallo-Olivé, J. NavasCastillo and A. L. Lourenção. 2020. Foliar Spraying of Tomato Plants with Systemic Insecticides: Effects on Feeding Behavior, Mortality and Oviposition of Bemisia tabaci (Hemiptera: Aleyrodidae) and Inoculation Efficiency of Tomato Chlorosis Virus. Insects. 11: 559. doi:10.3390/insects11090559.
Rojas, M.R., M.A.Macedo, M.R.Maliano, M.Soto-Aguilar, J.O. Souza, R.W.Briddon, L.Kenyon, R.F.R.Bustamante, F.M.Zerbini, S. Adkins... 2018. World Management of Geminiviruses. Annu. Revi. Phytopathol. 56: 637-677.

SAS (statistical analysis systems). 2016. Version 9.4 of the SAS System for Windows. Cary. NC, USA: SAS Institute Inc.

Shao-Jian Li, Xia Xue, Z. A. Muhammad, Shun-Xiang Ren,YuZhou Du, Jian-Hui Wu, G. S.Andrew Cuthbertson and B.Qiu. 2011. Host plants and natural enemies of Bemisia tabaci (Hemiptera: Aleyrodidae) in China. Insect Sci. 18: 101- $\quad 120 . \quad$ https://doi.org/10.1111/j.17447917.2010.01395.x

Siam, G. and T. Abdelhakim. 2018. Analysis of the tomato value chain in Egypt and establishment of an action plan to increase its efficiency. [Research Report] CIHEAMIAMM. pp.118. ffhal-02143775f.

Stansly, P.A. and E.T. Natwick. 2010. Integrated systems for managing Bemisia tabaci in protected and open field agriculture. p. 467-497. In: "Bemisia: Bionomics and Management of a Global Pest (P.A. Stansly, S.E. Naranjo, eds.). Springer. 540 .

\section{الملخص العربي}

\section{Bemisia tabaci تاثير بعض عناصر المكافحة المتكاملة علي الكثافة العددية لحشرة الذبابة البيضاء Solanum Iycopersicum L.علي نباتات الطماطم (Gennadius)}

$$
\text { عدنان عبدالفتاح السيد درويش، محمد مبروك رجب عطية، علاء مسعود حيطاوي خزيمي }
$$

بالسماد البوتاسي والفوسفاتي، واشارت النتائج الي وجود علاقة ارتباط موجبة بين السماد النيتروجيني وتعداد الذبابة وعلاقة ارتباط سالبة بين تعداد الذبابة والتسميد البوتاسي. وفيما يتعلق بالنشاط النهاري للحشرة الكاملة للذبابة البيضاء فأن النتائج بينت أن أعداد الذبابة البيضاء تكون أعلي معنويا في كلا من الساعة العاشرة والحادية عشر صباحا مقارنة ببقية ساعات النهار الأخري وتكررت هذه النتائج في كلا من العروة النيلية والعروة الصيفية. هذا ويمكن ترتيب المبيدات التي تم أختبارها علي تعداد الذبابة البيضاء كالآتي السلفوكسافلور sulfoxaflor، الثياميسوكسام thiamethoxam، الاسيتامبريد acetamiprid، البيريبروكسفين pyriproxphene، البيروفيزين buprofezin، واخيرا مبيد الداي نيتروفيوران dinotefuran.
الإدارة المتكاملة للذبابة البيضاء Bemisia tabaci تعتبر واحدة من أهم التحديات التي تواجه العلماء والمزارعين وذلك لتحقيق تتمية زراعية مستدامة. في هذا البحث تم دراسة تأثير كلا من مسافات الزراعة، نسب أو تراكيب مختلفة من الأسمدة الكيماوية، المعاملة بسليكات البوتاسيوم، النشاط النهاري للحشرة البالغة وكذلك تأثير المعاملة ببعض المبيدات الحشرية علي الكثافة العددية للحشرة علي نباتات الطماطم تحت ظروف الحقل المفتوح. أوضحت النتائج أن أقل كثافة عددية للحشرة تم تسجيلها علي أوراق نباتات الطماطم التي تم زراعتها علي مسافات • • سم. أوضحت النتائج أيضا أن السماد النيتروجيني كان العامل الرئيسي الذي يؤثر في تعداد الذبابة البيضاء مقارنة 